\title{
Neuroactive drugs-A perspective on drugs of synthetic and medicinal plants origin
}

\begin{abstract}
There is a gap between traditional knowledge, experimental proof and translational research into clinical studies for acceptance of traditional medicine. They are restricted by the quality of trials, flaws in study design and other important criteria that may affect their success as a clinically accepted drug. This article provides a summary of potential medicinal plants that can be used as natural psychotropic agents based on their fundamental scientific findings. Several reviews have been published that focus on a particular plant or particular neuronal disorder. This article focuses on providing a comprehensive review of different kinds of neuronal diseases, the shortcomings of psychotropic western medicine, the status of medicinal plants and their mechanism of action in various neuronal diseases. The article aims to emphasize establishing collaborative and concerted efforts between the ethnopharmacologists and western medicine practitioners to further provide scientific validation of traditional medicines.
\end{abstract}

Keywords: medicinal plants, neurological disorders
Volume 6 Issue 6 - 2018

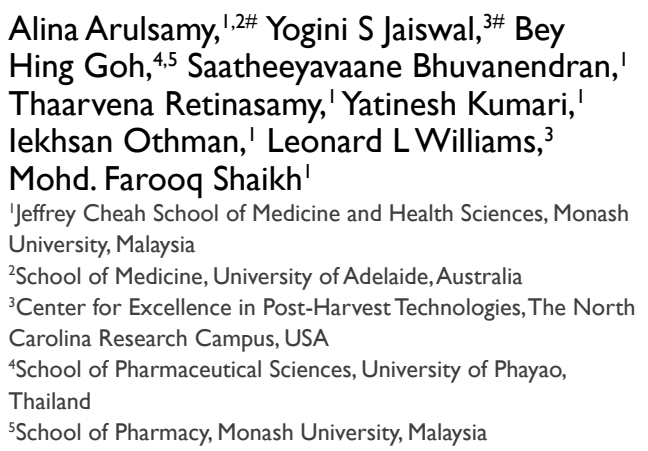

Correspondence: Mohd. Farooq Shaikh, Neuropharmacology Research Laboratory, Jeffrey Cheah School of Medicine and Health Sciences, Monash University Malaysia, Jalan Lagoon Selatan, 47500 Bandar Sunway, Selangor Darul Ehsan, Malaysia, Tel (603) 55।4-4483, Fax (603) 55I4 634I,

Email farooq.shaikh@monash.edu

Leonard Williams, Tel (704) 250-5700, Email Ilw@ncat.edu

\#A.Arulsamy and Y. Jaiswal have equally contributed to the work

Received: October 16,2018 | Published: November 16,2018

\section{Introduction}

\section{Neurological disorders}

Neurological disorders, specifically Alzheimer's (AD), Parkinson's (PD), depression, anxiety, and cognitive disorders, are indicated to have an increasing trend in their prevalence around the globe. ${ }^{1-4}$ According to the World Health Organization (WHO), more than 50 million people have epilepsy and about 35.6 million people are affected by AD or dementia globally. ${ }^{5}$ The increase in the prevalence of these conditions is likely due to the increase in life expectancy of people, as most neurological disorders are associated with old age or the impact of living a highly stressful life. Stress factors may be either oxidative or mechanical (trauma), or both and can cause functional changes in the brain that are associated with various brain disorders. ${ }^{6}$ Neurological disorders are divided into a number of categories such as neurodegenerative disorders (AD and PD), seizure disorders (epilepsy), mood disorders (anxiety and depression), genetic disorders (Huntington disease and Schizophrenia) and others (addiction, eating disorder, etc). $\mathrm{AD}$ and $\mathrm{PD}$ are disorders caused by the degeneration of neurons in different parts of the brain. Both these disorders are associated with age, where the build-up of beta-amyloid and tau protein (AD) or Lewy bodies (PD) over time, causes neuronal cell death. ${ }^{7,8}$ The AD is the most common type of dementia and $\mathrm{AD}$ patients suffer progressive functional impairment, cognitive decline (memory loss), loss of independence, emotional distress and behavioral symptoms. ${ }^{8}$ Similarly, PD patients also suffer from progressive functional impairment of motor neurons (tremors), emotional distress and autonomic symptoms. ${ }^{7}$
Unlike AD and PD, epilepsy is a disorder characterized by chronic unprovoked recurrent seizures that occur due to a sudden outburst of intense electrical impulses in the brain. ${ }^{9}$ Epilepsy is not governed by age or gender and can be brought on by traumatic injuries to the brain, infection, brain tumor, or congenital complications. ${ }^{7}$ Schizophrenia, on the other hand, is a common genetic mental disorder. A combination of genetic and environmental factors are known to contribute to the onset of schizophrenia. ${ }^{10,11}$ Depression is a serious long-term or recurrent mental illness that causes one to feel sad, guilty, tired, have low self-worth, and to lose the sense of pleasure. ${ }^{10}$ Anxiety disorders can be further classified into various types such as generalized anxiety disorder (GAD), obsessive-compulsive disorder (OCD), posttraumatic stress disorder (PTSD), social anxiety disorder, specific phobias, and other less common types.

\section{Synthetic Psychotropic drugs and their shortcomings}

Psychotropic drugs can be classified as anti-psychotic, anti-anxiety, antidepressants, psychomotor stimulants, psychotogenic drugs, and other miscellaneous categories. Various drug classes are used to treat different stages of any mental disorder, curb the probability of major side effects, and to account for the variability of drug pharmacology in different people. Psychotropic drugs have side effects after prolonged use, and adversely affect other systems of the body in addition to their central effects. Representative examples of each class of psychotropic drugs, and their central effects and side effects are presented in Table 1. Among the anti-depressant drug classes, selective serotonin reuptake inhibitors (SSRI) such as sertraline are the most commonly prescribed, due to reduced side effects compared to the other drugs in this class. ${ }^{35}$ 
SSRI and serotonin-norepinephrine reuptake inhibitors (SNRI) are second generation drugs and were developed to have less adverse effects than first-generation drugs such as tricyclic antidepressants (TCA) and monoamine oxidase inhibitors (MAOI) ${ }^{35,36}$ Nevertheless, first generation anti-depressants are prescribed to patients who do not tolerate or respond to second generation anti-depressants. In some occurrences, patients are also prescribed with a combination of antidepressant to increase effectiveness, but this poses the patients to the risk of drug-drug interactions and the resulting side effects. ${ }^{37,38}$ Antidepressant drugs even after discontinuation have serious side effects in some patients and these side effects are specific to the class of drugs used. ${ }^{39}$

Table I Central effects and side effects of drugs from different drug classes

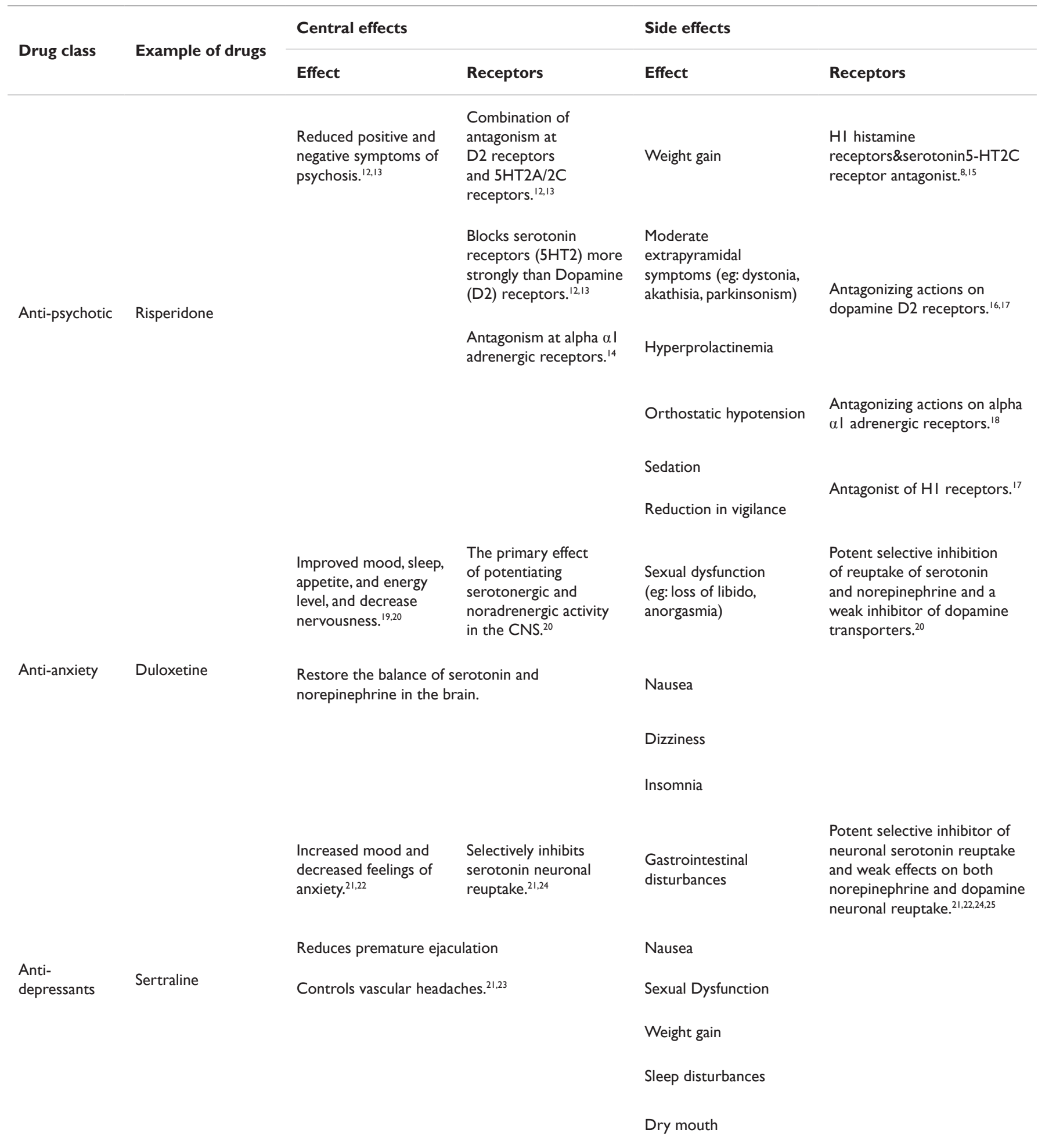


Table Continued....

Central effects $\quad$ Side effects

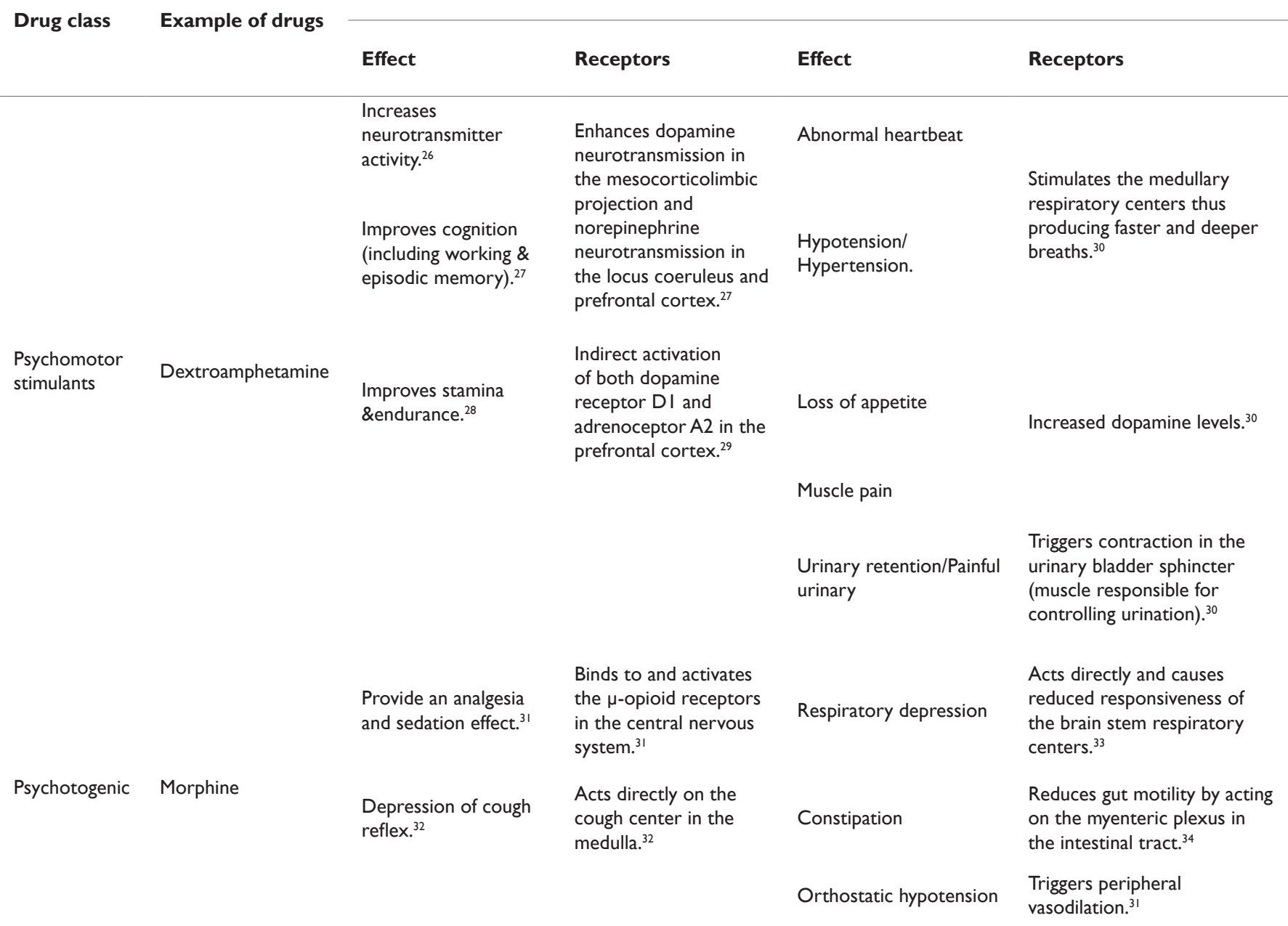

Anti-psychotic drugs (also known as major tranquilizers and neuroleptics) are primarily used in relieving symptoms of psychosis which are characteristic in certain mental health conditions like schizophrenia and bipolar disorder. ${ }^{40}$ Psychosis occurs due to the over-activity of the neurotransmitter, dopamine. It plays a vital role in memory, cognition, and is also relatively involved in controlling voluntary actions. Like drugs of other classes, anti-psychotics drugs also have major side effects. However, evidence suggests that some of the atypical drugs have milder movement-related side effects than the typical drugs. ${ }^{4-44}$ For example (as mentioned in Table 1), Risperidone is a newer "atypical" neuroleptic and it is more selective in action as compared to its counter partners, the "typical" neuroleptics. ${ }^{12-14}$ The atypical antipsychotics have little or no affinity for D1 receptors, thus they do not have the same side effects as observed with D1 antagonism, that the older first-generation antipsychotics exhibit. ${ }^{14,17,18}$ Regardless of the drug category used, the additional factors that alter the intensity of the side effects of drugs are the patient's tolerability, susceptibility to the type of drug as well as the severity of the disorder being treated. Currently, most studies focus on synthetic drugs as treatment options for mental disorders, however, there are many populations with inadequate access to these treatments. ${ }^{45}$ In these populations, traditional and herbal treatments are only available options, and therefore we wish to examine these in our article..$^{45}$

\section{Neuroactive medicinal plants and their pre-clinical testing}

Formulations from Traditional systems of medicine have been used for centuries globally, despite the increased acceptance of western medicine in therapy. The continued use of traditional medicine and their demand outweighs the benefit to risk ratio consideration by patients. There are several medicinal plants which have been used by traditional medicine practitioners to treat various neurological disorders. Based on a literature survey of neuroactive medicinal plants, a list of medicinal plant varieties and their pre-clinical evaluation data is provided in Table 2. Curcumin, a potent active compound found in turmeric, acts as an anti-inflammatory compound by inhibiting proinflammatory cytokines (TNF- $\alpha$, IL-1 $\beta$, IL-6) that can be generated by neurodegenerative diseases. ${ }^{67}$ Gotu Kola, also known as an Indian penny-wort, has been traditionally used as a brain tonic in Ayurvedic medicine for decades. Hyperricumperforatum is used to treat mild to moderate depression and Bacopamonniera is used as an anxiolytic agent. ${ }^{68,69}$ Oxidative stress and mitochondrial failure will eventually lead to the development of AD. Preclinical studies have shown that Gingko Biloba extracts have antioxidant properties which reduce oxidative stress and improve mitochondrial respiration and therefore may be useful in preventing or slowing down the progression of the 
AD (2015). Ginsenoside isolated from ginseng extracts have reported having properties of preventing neuronal damage caused due to beta-amyloid-induced neurotoxicity and therefore is considered to be a potential agent in the treatment of $\mathrm{AD} .{ }^{70}$ All these examples demonstrate the importance and long-standing role of various natural products in treating numerous mental disorders.

Table $2 \mathrm{~A}$ collection of animal studies of medicinal plants in neurological disorder and their scientific data

\begin{tabular}{|c|c|c|c|c|}
\hline Plant & Animals & Dose & Obtained pharmacological effect & Potential compound(s) responsible \\
\hline $\begin{array}{l}\text { Hypericum } \\
\text { perforatum }\end{array}$ & $\begin{array}{l}\text { Normal male CD } \\
\text { rats }\end{array}$ & $0.3-480 \mathrm{mg} / \mathrm{kg}$ & Showed antidepressant activity in FST & $\begin{array}{l}\text { Hyperoside, isoquercitrin, miquelianin, aglycone } \\
\text { quercetin. }{ }^{6}{ }^{6}\end{array}$ \\
\hline Salvia elegans & $\begin{array}{l}\text { Normal male ICR } \\
\text { mice }\end{array}$ & $25-2000 \mathrm{mg} / \mathrm{kg}$ & $\begin{array}{l}\text { Showed antidepressant activities in } \\
\text { EPM, L-DT, FST, and OFT. }{ }^{47}\end{array}$ & - \\
\hline Ginkgo biloba & $\begin{array}{l}\text { Normal male CD } \\
\text { rats }\end{array}$ & 5,10 and $50 \mathrm{mg} / \mathrm{kg}$ & $\begin{array}{l}\text { Showed antidepressant activities in FST } \\
\text { and TST }\end{array}$ & $\begin{array}{l}\text { Composition: } 8.2 \% \text { quercetin glycosides, } 6.4 \% \\
\text { kaempferol glycosides, I.6\% methylmyricetin } \\
\text { glycosides, } 2.98 \% \text { bilobalide, I.59\% ginkgolide A, } \\
\text { I.16\% ginkgolide B and } 0.75 \% \text { ginkgolide C. }{ }^{48}\end{array}$ \\
\hline $\begin{array}{l}\text { Crocus } \\
\text { sativus } L .\end{array}$ & $\begin{array}{l}\text { Normal Male ICR } \\
\text { mice }\end{array}$ & $\begin{array}{l}\text { I50, } 300 \text { and } 600 \mathrm{mg} / \\
\mathrm{kg}\end{array}$ & $\begin{array}{l}\text { Showed antidepressant activities in FST } \\
\text { and TST }\end{array}$ & Hexadecanoic acid, crocin I. ${ }^{49}$ \\
\hline $\begin{array}{l}\text { Morinda } \\
\text { officinalis }\end{array}$ & $\begin{array}{l}\text { Male Kuming mice } \\
\text { and male Wistar } \\
\text { rats (DRL72-s } \\
\text { schedule) }\end{array}$ & $\begin{array}{l}12.5,25,50,100 \text { and } \\
200 \mathrm{mg} / \mathrm{kg}\end{array}$ & Showed antidepressant activity in FST. ${ }^{50}$ & - \\
\hline $\begin{array}{l}\text { Centella } \\
\text { asiatica L }\end{array}$ & $\begin{array}{l}\text { Normal male } \\
\text { Sprague Dawley } \\
\text { Rats with olfactory } \\
\text { bulbectomy }\end{array}$ & $3,10,30 \mathrm{mg} / \mathrm{kg}$ & $\begin{array}{l}\text { Showed antidepressant activities in } \\
\text { OFT and EPM. }{ }^{51}\end{array}$ & - \\
\hline $\begin{array}{l}\text { Piper } \\
\text { laetispicum }\end{array}$ & $\begin{array}{l}\text { Normal KM male } \\
\text { Mice }\end{array}$ & $30,60,120 \mathrm{mg} / \mathrm{kg}$ & $\begin{array}{l}\text { Showed antidepressant activities in } \\
\text { OFT and FST }\end{array}$ & Laetispicine and Leatispiamide $A .^{52}$ \\
\hline $\begin{array}{l}\text { Curcuma } \\
\text { longa }\end{array}$ & $\begin{array}{l}\text { Normal Male ICR } \\
\text { Mice }\end{array}$ & $140,280,560 \mathrm{mg} / \mathrm{kg}$ & $\begin{array}{l}\text { Showed antidepressant activities in TST, } \\
\text { FST and MAO inhibition in the brain. }{ }^{53}\end{array}$ & - \\
\hline $\begin{array}{l}\text { Bacopa } \\
\text { monniera }\end{array}$ & $\begin{array}{l}\text { Charles-Foster } \\
\text { albino rats }\end{array}$ & $20,40 \mathrm{mg} / \mathrm{kg}$ & $\begin{array}{l}\text { Showed antidepressant activities in FST } \\
\text { and LHM }\end{array}$ & Bacoside $\mathrm{A}^{54}$ \\
\hline $\begin{array}{l}\text { Withania } \\
\text { somnifera }\end{array}$ & $\begin{array}{l}\text { Charles Foster } \\
\text { male rats }\end{array}$ & $20,50 \mathrm{mg} / \mathrm{kg}$ & $\begin{array}{l}\text { Showed antidepressant activities in FST } \\
\text { and LHT. Lowered endocoid marker, } \\
\text { tribulin. }\end{array}$ & Glycowithanolides ${ }^{55}$ \\
\hline $\begin{array}{l}\text { Panax } \\
\text { notoginseng }\end{array}$ & $\begin{array}{l}\text { Male } K M \text { mice and } \\
\text { male SD rats }\end{array}$ & $\begin{array}{l}10,30,100,300 \\
1000 \mathrm{mg} / \mathrm{kg}\end{array}$ & $\begin{array}{l}\text { Showed antidepressant activities in FST. } \\
\text { Increases levels of 5-HT, Dopamine, and } \\
\text { noradrenaline. Lowered intracellular } \\
\mathrm{Ca} 2+\end{array}$ & Ginsenosides, Notoginsenosides, gypenosides. ${ }^{56}$ \\
\hline $\begin{array}{l}\text { Areca } \\
\text { catechu }\end{array}$ & Male Wistar Rats & $\begin{array}{l}4,10,13,50,80 \\
100 \mathrm{mg} / \mathrm{kg} \text { (Extract) } \\
2.5,4,5,10,13,16 \mathrm{mg} / \\
\mathrm{kg} \text { (Clorgyline) }\end{array}$ & $\begin{array}{l}\text { Showed antidepressant activities in FST, } \\
\text { TST }\end{array}$ & Clorgyline $^{57}$ \\
\hline $\begin{array}{l}\text { Bupleuri } \\
\text { radix }\end{array}$ & $\begin{array}{l}\text { Male Sprague- } \\
\text { Dawley rats. In- } \\
\text { vitro culture of } \\
\text { SH-SY5Y cell line. }\end{array}$ & $\begin{array}{l}600 \text { and } 900 \mathrm{mg} / \mathrm{kg} 10 \\
100,1000 \mu g / \mathrm{ml}\end{array}$ & $\begin{array}{l}\text { Showed antidepressant activity in FST. } \\
\text { Increased CREB phosphorylation and } \\
\text { BDNF levels. }{ }^{58}\end{array}$ & - \\
\hline $\begin{array}{l}\text { Hemerocallis } \\
\text { citrina }\end{array}$ & Male ICR mice & $90,180,360 \mathrm{mg} / \mathrm{kg}$ & $\begin{array}{l}\text { Showed antidepressant activities in FST, } \\
\text { TST }^{59}\end{array}$ & - \\
\hline $\begin{array}{l}\text { Byrsonima } \\
\text { crassifolia }\end{array}$ & ICR albino mice & $500 \mathrm{mg} / \mathrm{kg}$ & Showed antidepressant activity in FST & Rutin, quercetin, hesperidin ${ }^{60}$ \\
\hline $\begin{array}{l}\text { Passiflora } \\
\text { edulis }\end{array}$ & $\begin{array}{l}\text { Male and Female } \\
\text { ICR mice }\end{array}$ & $\begin{array}{l}384,452,1920, \\
2260 \mathrm{mg} / \mathrm{kg} \text { (Extract) } \\
50 \mathrm{mg} / \mathrm{kg} \text { (compounds) }\end{array}$ & $\begin{array}{l}\text { Showed antidepressant activities in } \\
\text { TST, FST }\end{array}$ & Cyclo passifloic acid IX, Cyclopassifloic acid $X^{61}$ \\
\hline $\begin{array}{l}\text { Ceratonia } \\
\text { siliqua }\end{array}$ & Male Albino Mice & $25,50 \mathrm{mg} / \mathrm{kg}$ & $\begin{array}{l}\text { Showed antidepressant activities in } \\
\text { FST,TST, might act through adrenergic } \\
\text { ( } \alpha \text { I-adrenoceptors) and dopaminergic } \\
\text { (dopamine D2 receptors) }^{62}\end{array}$ & - \\
\hline
\end{tabular}


Table Continued...

\begin{tabular}{|c|c|c|c|c|}
\hline Plant & Animals & Dose & Obtained pharmacological effect & Potential compound(s) responsible \\
\hline $\begin{array}{l}\text { Hypericum } \\
\text { montbretti }\end{array}$ & $\begin{array}{l}\text { Male Swiss albino } \\
\text { mice }\end{array}$ & $100,250 \mathrm{mg} / \mathrm{kg}$ & $\begin{array}{l}\text { Showed antidepressant activities in } \\
\text { TST, FST }\end{array}$ & Rutin, Quercitrin ${ }^{63}$ \\
\hline $\begin{array}{l}\text { Tagetes } \\
\text { lucida }\end{array}$ & Male Wistar rats & $100-1000 \mathrm{mg} / \mathrm{kg}$ & Showed antidepressant activity in $\mathrm{FST}^{64}$ & - \\
\hline $\begin{array}{l}\text { Glycyrrhiza } \\
\text { uralensis }\end{array}$ & $\begin{array}{l}\text { Male Sprague- } \\
\text { Dawley rats }\end{array}$ & $10,20,40 \mathrm{mg} / \mathrm{kg}$ & $\begin{array}{l}\text { Showed antidepressant activities in FST, } \\
\text { increased sucrose consumption, might } \\
\text { act through antioxidant pathways as } \\
\text { an observed increase of SOD activity, } \\
\text { inhibition of lipid peroxidation and } \\
\text { lessen the production of MDA }\end{array}$ & Liquiritin $^{65}$ \\
\hline $\begin{array}{l}\text { Alchornea } \\
\text { cordifolia }\end{array}$ & $\begin{array}{l}\text { Swiss albino mice } \\
\text { either sex }\end{array}$ & $50,100,200,400 \mathrm{mg} / \mathrm{kg}$ & Showed antidepressant activity in FST ${ }^{66}$ & - \\
\hline
\end{tabular}

Passiflora (passion flower extract) and valerian are two well studied medicinal plants and a number of preclinical and clinical studies demonstrate the effectiveness of these two herbs in treating anxiety, depression and sleep disorders. ${ }^{62,70}$ Many polyherbal formulations available commercially or in clinical phases for treating anxiety contain passiflora and valerian as their active component. ${ }^{61,63,64,71-73}$ Various in-vivo models used for the study of the activity of medicinal plants in the treatment of neurological disorders mentioned in Table 2. It is found that most of the medicinal plants found to be active in animal models have flavonoids (quercetin, iso-quercitin, catechin, rutin, hesperidin), terpenoids (ginkgolide $\mathrm{A}$, ginkgolide $\mathrm{B}$ and ginkgolide $\mathrm{C}$, hederagenin, Podoandin), amide alkaloids (Leatispiamide A), saponins (Bacoside A), phytosterols (stigmasterol), coumarins (Scopoletin), opioid (Mitragynine) and other constituents as active agents (Figure 1). There are several widely accepted and established animal models of experiments being used for in-vivo evaluation for many mental disorders. ${ }^{7475}$ For example, learning and memory models such as radial arm maze, Morris water maze, and y-maze are used to evaluate the effect of medicinal plant extracts in Alzheimer's disease in rats. The basis of learning and memory animal models is to determine how a normal or treated, and damaged or untreated brain processes and retains information when confronted with the psychological nature of a certain task. ${ }^{76}$ For mood disorders due to anxiety, elevated plus maze is a commonly used model while tail suspension test and forced swim test is used for depression studies. Depression experimental models are designed based on a concept known as "searching-waiting strategy". ${ }^{77}$ Theoretically, in these, the tests, a normal animal subjected to an aversive situation alternates between two kinds of behavior, agitation, and immobility. These can be named as searching-behavior characterized by intense motor activity and expense of energy, and as waiting-behavior characterized by immobility and energy saving. The choice sequences between these kinds of behavior can be named as the searching-waiting strategy.
(A)<smiles>O=c1c(O)c(-c2ccc(O)c(O)c2)oc2cc(O)cc(O)c12</smiles>

Quercitin

(B)

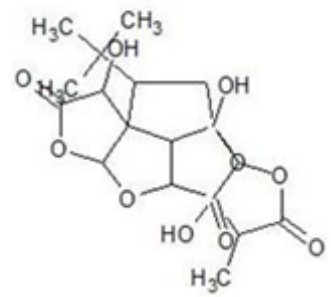

Ginkgolide B

(C)

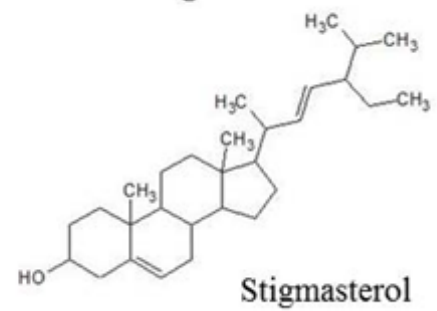

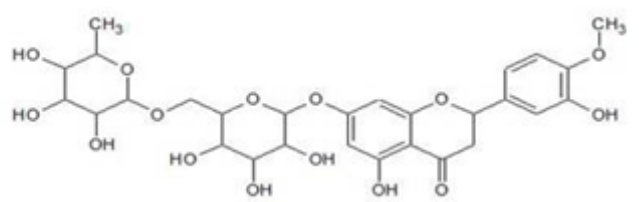

Hesperidin<smiles>CC[C@]12CC[C@]3(C(=O)O)CCC(C)(C)CC3C1=CC[C@@H]1C(C)(CO)C(O)CCC12C</smiles>

Hederagenin<smiles>COc1cc2ccc(=O)oc2cc1O</smiles>

Scopoletin<smiles>Oc1cc(O)c2c(c1)OC(c1ccc(O)c(O)c1)C(O)C2</smiles>

Catechin<smiles>CC1=CCC2=C(C)CC3OC(=O)C(C)=C3CC12</smiles><smiles>COCC1CC2c3[nH]c4cccc(OC)c4c3CC2C(=O)OC1(C)C</smiles>

Mitragynine

Figure I Phytoconstituents reported in neuroactive medicinal plants. 


\section{Mechanism of action of neuroactive medicinal plants}

Medicinal plants have been studied in various in-vivo and in-vitro models and have been reported to have their effects through various pathways in different neuronal disorders. It is difficult to identify the exact phytoconstituents and the mechanism of responsible for any pharmacological effect of plant-based products. Mechanism of action is reported or suggested only by few extensive studies.

Depression and anxiety: Most plants with anti-depressant and antianxiolytic effect are reported to show activity in mild to moderate conditions. Plants that exhibited anxiolytic activity are suggested to possess such effect due to binding of their active phytoconstituents to cholecystokinin (CCK) receptors which are known to affect the pathophysiological processes of fear and anxiety. ${ }^{78}$ Benzodiazepine receptor (alpha subunit) binding effect has been reported from guinea pig brains in plants with anxiolytic effect. ${ }^{79}$ Anti-anxiety extracts are reported to have an effect on the Gamma Amino Butyric Acid (GABA) receptors, the voltage-gated channels and ionic transmission in the brain. Increased GABA neurotransmission leads to a calming effect in patients. Plants are reported to have not only a GABAnergic effect but also serotonergic and dopaminergic activities. ${ }^{80}$

Obsessive-compulsive disorder (OCD): Some plants are reported to have beneficial effects in the treatment of OCD in in-vivo models and it is postulated that the plant extracts exhibit this activity through serotonin reuptake inhibitors or due to blockage of serotonergic neurotransmission, specifically the 5-hydroxytryptamine receptors (5-HT) receptors. ${ }^{81,82}$

Cognition, sleep disorders and Alzheimer's disease: Plant extracts are reported to exhibit properties of improving cognition through their anti-oxidant properties. It is hypothesized that neuronal protection is offered through anti-oxidant activity and this prevents neuronal cell death caused due to excessive exposure to glutamate. Anti-oxidant properties also lead to reduced beta-amyloid toxicity which makes such plants as good candidates for the treatment of Alzheimer's disease. ${ }^{83,84}$ Some plant extracts are proposed to have memory enhancing and antianxiety effect due to their ability to bind to cholecystokinin receptors (CCKB) which bind to the hormone cholecystokinin (CCK) ${ }^{85}$

Schizophrenia: Phytoconstituents liked cannabidiol (CBD) are reported to be effective in the treatment of psychosis or Schizophrenia. It is hypothesized that $\mathrm{CBD}$ has the potential to activate the 5-HT receptor and transient receptor potential cation channel subfamily $\mathrm{V}$ member 1 (TrpV1). CBD also restricts the degradation of anandamide (AEA) and facilitates the blockage of G protein-coupled receptor 55. These activities lead to the probable anti-psychotic effect of plants effective in the treatment of Schizophrenia. ${ }^{86,87}$

Parkinson's disease: In animal studies, some plant extracts lead to decrease in apoptosis and reduced neuronal damage caused due to their interaction with Mitogen-activated protein kinases (MAPK), Phosphatidylinositol 3-kinase (PI3K/Akt) and protein kinase C. ${ }^{88}$ Phytoconstituents such as ginsenosides exhibit potential to inhibit dopamine uptake and act as NMDA antagonists. This protects neurons from the increase in glutamate levels and dysfunction of the mitochondria. ${ }^{28,89}$

\section{Challenges for acceptance of medicinal plants}

A number of drugs in use today are from plant sources and since the last several decades, herbal medicines have made their place in major pharmacopeias of various traditional systems of medicine, across the globe. ${ }^{90}$ A substantial amount of pre-clinical studies carried out under strict scrutiny of the concerned animal ethics committee and acceptable results for testing in humans can make an investigational herbal drug qualified for a clinical trial. The complexity of herbal formulations, the synergistic effect or interactions between various constituents and regulatory issues impose a large number of challenges for the herbal medicines to be selected for clinical trials and be successfully accepted as drugs. ${ }^{91}$ In the year 2005, WHO published a report that provides operational guidelines for clinical trials of herbal medicines. The report emphasizes that herbal drugs are faced by four major challenges that include ethical concerns, quality control procedures during manufacturing, and non-clinical and clinical issues. ${ }^{92}$ In the recent decades, a number of herbal medicines as single herb extract or as polyherbal formulations have been subjected to testing in clinical trials. A number of reports and reviews are available that show the viability of randomized clinical trials of herbal medicines. Literature reveals many herbal formulations that were subjected to clinical trials for the treatment of neurological disorders. Many clinical trials of herbal medicines were not successfully completed due to a lack of robust study design, difficulty in the selection of specific controls, and patient-related factors. ${ }^{91}$ Trials of medicinal plants such as St. St John's wort have failed because of low assay sensitivity and the absence of a trend in the efficacy evaluations. ${ }^{69}$

\section{Conclusion}

There are hundreds of natural products including individual herb and polyherbal formulations which have been characterized and evaluated for their effectiveness in various neurological disorders in preclinical experiments and randomized clinical trials. The majority of the clinical trials were non-conclusive and unable to provide strong evidence to establish the effectiveness of each natural product. ${ }^{93-97}$ There is a huge gap in bringing these active herbs to patients in the clinics. There is an abundance of potential natural products that have not been examined yet. The strong collaborative effort between ethno pharmacologists and clinical neurologists and extensive supporting initiatives from the regulatory and governmental bodies for herbal drug research is required to overcome the challenges that herbal drugs face in their acceptance for clinical treatment.

\section{Acknowledgements}

Authors are thankful to NKEA Research Grant Scheme (NRGS), Ministry of Agriculture and Agro-Based Industry Malaysia (Grant No. NH1014D066) for providing funding support. The authors are thankful to Aaron Yerke, for editing the manuscript for its language and contents.

\section{Conflict of interest}

Authors declare that there is no conflict of interest(s)

\section{References}

1. Gourie-Devi M. Epidemiology of neurological disorders in India: review of background, prevalence and incidence of epilepsy, stroke, Parkinson's disease and tremors. Neurol India. 2014;62(6):588-598.

2. Hebert LE, Weuve J, Scherr PA. Alzheimer disease in the United States (2010-2050) estimated using the 2010 census. Neurology. 2013;80(19):1778-1783.

3. Hidaka BH. Depression as a disease of modernity: explanations for increasing prevalence. J Affect Disord. 2012;140(3):205-214.

4. Liu WM, Wu RM, Lin JW, et al. Time trends in the prevalence and incidence of Parkinson's disease in Taiwan: A nationwide, populationbased study. J Formos Med Assoc. 2016;115(7):531-538. 
5. WHO-Neurological Disorders: Public Health Challenges. Geneva: WHO; 2016.

6. Alkadhi K. Brain Physiology and Pathophysiology in Mental Stress. ISRN Physiology. 2013;806104:1-23.

7. Surguchov A. Parkinson's disease: Is there a light at the end of a tunnel? Adv Park Dis. 2013;2(4):116.

8. Williams JW, Plassman BL, Burke J, et al. Preventing Alzheimer's Disease and Cognitive Decline. Evid Rep Technol Assess. 2010;193:1727.

9. Arulsamy A, Goh BH, Shaikh MF. Current status of epilepsy in malaysia and way ahead. Int J Pharm Pharm Sci. 2014;7(1):2-5.

10. Irmak MK. Schizophrenia or Possession? J Relig Health. 2014;53(3):773777.

11. Pickard B. Progress in defining the biological causes of schizophrenia. Expert Rev Mol Med. 2011;13:e25.

12. Ebdrup BH, Rasmussen H, Arnt J, et al. Serotonin 2A receptor antagonists for treatment of schizophrenia. Expert Opin Investig Drugs. 2011;20(9):1211-1223.

13. Kapur S, Zipursky RB, Remington G. Clinical and theoretical implications of 5-HT2 and D2 receptor occupancy of clozapine, risperidone, and olanzapine in schizophrenia. Am J Psychiatry. 1999;156(2):286-293.

14. Hecht EM, Landy DC. Alpha-2 receptor antagonist add-on therapy in the treatment of schizophrenia; a meta-analysis. Schizophr Res. 2012;134(23):202-206.

15. Calarge CA, Acion L, Kuperman S, et al. Weight gain and metabolic abnormalities during extended risperidone treatment in children and adolescents. J Child Adolesc Psychopharmacol. 2009;19(2):101-109.

16. Bostwick JR, Guthrie SK, Ellingrod VL. Antipsychotic-induced hyperprolactinemia. Pharmacotherapy. 2009;29(1):64-73.

17. Gentile S. Adverse effects associated with second-generation antipsychotic long-acting injection treatment: a comprehensive systematic review. Pharmacotherapy. 2013;33(10):1087-1106.

18. Gugger JJ. Antipsychotic pharmacotherapy and orthostatic hypotension: identification and management. CNS Drugs. 2011;25(8):659-671.

19. Lee SI, Keltner NL. Biological perspectives. Serotonin and norepinephrine reuptake inhibitors (SNRIs): venlafaxine and duloxetine. Perspect Psychiatr Care. 2006;42(2):144-148.

20. Trivedi MH, Desaiah D, Ossanna MJ, et al. Clinical evidence for serotonin and norepinephrine reuptake inhibition of duloxetine. Int Clin Psychopharmacol. 2008;23(3):161-169.

21. Kaprinis S, Parlapani E, Raikos N, et al. Psychotic episode associated with sertraline and drug-related delirium: a case report. J Clin Psychopharmacol. 2014;34(4):527-529.

22. Sansone RA, Sansone LA. Serotonin Norepinephrine Reuptake Inhibitors: A Pharmacological Comparison. Innov Clin Neurosci. 2014;11(3-4):37-42.

23. Moja PL, Cusi C, Sterzi RR, et al. Selective serotonin re-uptake inhibitors (SSRIs) for preventing migraine and tension-type headaches. Cochrane Database Syst Rev. 2005;3:CD002919.

24. Arafa M, Shamloul R. Efficacy of sertraline hydrochloride in treatment of premature ejaculation: a placebo-controlled study using a validated questionnaire. Int J Impot Res. 2006;18(6):534-538.

25. Ferguson JM. SSRI Antidepressant Medications: Adverse Effects and Tolerability. Prim Care Companion J Clin Psychiatry. 2001;3(1):22-27.

26. Bidwell LC, McClernon FJ, Kollins SH. Cognitive enhancers for the treatment of ADHD. Pharmacol Biochem Behav. 2011;99(2):262-274.
27. Wood S, Sage JR, Shuman T, et al. Psychostimulants and Cognition: A Continuum of Behavioral and Cognitive Activation. Pharmacol Rev. 2014;66(1):193-221.

28. Beal MF, Brouillet E, Jenkins B, et al. Age-Dependent Striatal Excitotoxic Lesions Produced by the Endogenous Mitochondrial Inhibitor Malonate. J Neurochem. 1993;61(3):1147-1150.

29. Liddle DG, Connor DJ. Nutritional supplements and ergogenic AIDS Prim Care. 2013;40(2):487-505.

30. Westfall TC, Westfall DP. Adrenergic Agonists and Antagonists. In: Brunton LL, et al. editors, Goodman \& Gilman's: The Pharmacological Basis of Therapeutics. New York: McGraw-Hill Education; 2011.

31. Meine TJ, Roe MT, Chen AY, et al. Association of intravenous morphine use and outcomes in acute coronary syndromes: results from the CRUSADE Quality Improvement Initiative. Am Heart J. 2005;149(6):1043-1049.

32. Duggan ST, Scott LJ. Morphine/naltrexone. CNS Drugs. 2010;24(6):527538.

33. Smith LH. Opioid safety: is your patient at risk for respiratory depression? Clin J Oncol Nurs. 2007;11(2):293-296.

34. Calignano A, Moncada S, Di Rosa M. Endogenous nitric oxide modulates morphine-induced constipation. Biochem Biophys Res Commun. 1991;181(2):889-893.

35. Bylund DB. Selecting selectivities and the neuropharmacology of antidepressant drug action A commentary. FASEB J. 2007;21(13):34173418.

36. Gartlehner G, Hansen RA, Thieda P, et al. Comparative Effectiveness of Second-Generation Antidepressants in the Pharmacologic Treatment of Adult Depression, AHRQ Comparative Effectiveness Reviews. Rockville: Agency for Healthcare Research and Quality (US); 2007.

37. Palaniyappan L, Insole L, Ferrier N. Combining antidepressants: a review of evidence. Adv Psychiatr Treat. 2009;15(2):90-99.

38. Shultz E, Malone DA. A practical approach to prescribing antidepressants. Cleve Clin J Med. 2013;80(10):625-631.

39. Haddad PM, Anderson IM. Recognising and managing antidepressant discontinuation symptoms. Adv Psychiatr Treat. 2007;13(6):447-457.

40. Leucht S, Corves C, Arbter D, et al. Second-generation versus firstgeneration antipsychotic drugs for schizophrenia: a meta-analysis. Lancet. 2009;373(9657):31-41.

41. Fischer-Barnicol D, Lanquillon S, Haen E, et al. Typical and atypical antipsychotics--the misleading dichotomy. Results from the Working Group "Drugs in Psychiatry" (AGATE). Neuropsychobiology. 2008;57(1-2):80-87.

42. Hartling L, Abou-Setta AM, Dursun S, et al. Antipsychotics in Adults with Schizophrenia: Comparative Effectiveness of First-Generation Versus Second-Generation Medications: A Systematic Review and Metaanalysis. Ann Intern Med. 2012;157(7):498-511.

43. Kane JM, Correll CU. Pharmacologic treatment of schizophrenia Dialogues Clin Neurosci. 2010;12(3):345-357.

44. Jarema M, Wichniak A, Dudek D, et al. Guidelines for the use of secondgeneration long-acting antipsychotics. Psychiatr Pol. 2015;49(2):225241.

45. Debas HT, Laxminarayan R, Straus SE. Complementary and Alternative Medicine. In: Jamison DT, et al. editors, Disease Control Priorities in Developing Countries. Washington (DC): World Bank; 2006.

46. Butterweck V, Jürgenliemk G, Nahrstedt A, et al. Flavonoids from Hypericum perforatum show antidepressant activity in the forced swimming test. Planta Med. 2000;66(1):3-6. 
47. Herrera-Ruiz M, García-Beltrán Y, Mora S, et al. Antidepressant and anxiolytic effects of hydroalcoholic extract from Salvia elegans. $J$ Ethnopharmacol. 2006;107(1):53-58.

48. Sakakibara H, Ishida K, Grundmann O, et al. Antidepressant effect of extracts from Ginkgo biloba leaves in behavioral models. Biol Pharm Bull. 2006;29(8):1767-1770.

49. Wang Y, Han T, Zhu Y, et al. Antidepressant properties of bioactive fractions from the extract of Crocus sativus L. J Nat Med. 2010;64(1):2430.

50. Zhang ZQ, Yuan L, Yang M, et al. The effect of Morinda officinalis How, a Chinese traditional medicinal plant, on the DRL 72-s schedule in rats and the forced swimming test in mice. Pharmacol Biochem Behav. 2002; $72(1-2): 39-43$.

51. Kalshetti PB, Alluri R, Thakurdesai PA, et al. Antidepressant effects of standardized extract of Commiphora mukul Engl. in olfactory bulbectomized rats. Braz Arch Biol Technol. 2015;58(1):41-48.

52. Xie H, Yan M, Jin D, et al. Studies on antidepressant and antinociceptive effects of ethyl acetate extract from Piper laetispicum and structureactivity relationship of its amide alkaloids. Fitoterapia. 2011;82(7):10861092.

53. Yu ZF, Kong LD, Chen Y. Antidepressant activity of aqueous extracts of Curcuma longa in mice. J Ethnopharmacol. 2002;83(1-2):161-165.

54. Sairam K, Dorababu M, Goel RK, et al. Antidepressant activity of standardized extract of Bacopa monniera in experimental models of depression in rats. Phytomedicine. 2002;9(3):207-211.

55. Bhattacharya SK, Bhattacharya A, Sairam K, et al. Anxiolyticantidepressant activity of Withania somnifera glycowithanolides: an experimental study. Phytomedicine. 2000;7(6):463-469.

56. Xiang H, Liu Y, Zhang B, et al. The antidepressant effects and mechanism of action of total saponins from the caudexes and leaves of Panax notoginseng in animal models of depression. Phytomedicine. 2011;18(89):731-738.

57. Dar A, Khatoon S. Antidepressant Effects of Ethanol Extract of Areca catechu in Rodents. Phytother Res. 1997;11(2):174-176.

58. Seo MK, Song JC, Lee SJ, et al. Antidepressant-like effects of Bupleur Radix extract. Eur J Integr Med. 2012;4(4):e392-e399.

59. Gu L, Liu YJ, Wang YB, et al. Role for monoaminergic systems in the antidepressant-like effect of ethanol extracts from Hemerocallis citrina. $J$ Ethnopharmacol. 2012;139(3):780-787.

60. Herrera-Ruiz M, Zamilpa A, González-Cortazar M, et al. Antidepressant effect and pharmacological evaluation of standardized extract of flavonoids from Byrsonima crassifolia. Phytomedicine. 2011;18(14):1255-1261.

61. Wang C, Xu FQ, Shang JH, et al. Cycloartane triterpenoid saponins from water soluble of Passiflora edulis Sims and their antidepressant-like effects. J Ethnopharmacol. 2013;148(3):812-817.

62. Subhan F, Karim N, Gilani AH, et al. Terpenoid content of Valeriana wallichii extracts and antidepressant-like response profiles. Phytother Res. 2010;24(5):686-691.

63. Liu XG, Gao PY, Wang GS, et al. In vivo antidepressant activity of sesquiterpenes from the roots of Valeriana fauriei Briq. Fitoterapia. 2012;83(3):599-603.

64. Müller LG, Salles LA, Stein AC, et al. Antidepressant-like effect of Valeriana glechomifolia Meyer (Valerianaceae) in mice. Prog Neuropsychopharmacol Biol Psychiatry. 2012;36(1):101-109.

65. Dhingra D, Valecha R. Evaluation of antidepressant-like activity of aqueous and ethanolic extracts of Terminalia bellirica Roxb. fruits in mice. Indian J Exp Biol. 2007;45(7):610-616.
66. Dhingra D, Valecha R. Screening for antidepressant-like activity of Convolvulus pluricaulis Choisy in mice. Pharmacologyonline. 2007; 1:262-278.

67. Tizabi Y, Hurley LL, Qualls Z, et al. Relevance of the anti-inflammatory properties of curcumin in neurodegenerative diseases and depression. Molecules. 2014;19(12):20864-20879.

68. Orhan IE. Centella asiatica (L.) Urban: From Traditional Medicine to Modern Medicine with Neuroprotective Potential. Evid Based Complement Alternat Med. 2012;946259:1-8.

69. Wurglics M, Schubert-Zsilavecz M. Hypericum perforatum: a "modern" herbal antidepressant: pharmacokinetics of active ingredients. Clin Pharmacokinet. 2006;45(5):449-468.

70. Yoo KY, Park SY. Terpenoids as potential anti-Alzheimer's disease therapeutics. Molecules. 2012;17(3):3524-3538.

71. Acharya DK. Effects of psychological imbalances in cancer patients and its management. Antiseptic. 2000;97:234.

72. Association of Passiflora Incarnata L; Crataegus Oxyacantha L and Salix Alba L. on Mild and Moderate Anxiety. Bethesda: National Library of Medicine (US); 2012.

73. Bourin M, Bougerol T, Guitton B, et al. A combination of plant extracts in the treatment of outpatients with adjustment disorder with anxious mood: controlled study versus placebo. Fundam Clin Pharmacol. 1997;11(2):127-132.

74. Chatelain E, Konar N. Translational challenges of animal models in Chagas disease drug development: a review. Drug Des Devel Ther. 2015;9:4807-4823.

75. Van der Staay FJ, Arndt SS, Nordquist RE. Evaluation of animal models of neurobehavioral disorders. Behav Brain Funct. 2009;5:11.

76. Narwal S, Saini DR, Kumari K, Narwal S, et al. Behavior \& pharmacological animal models for the evaluation of learning \& memory condition. Indo Glob J Pharm Sci. 2012;2(2):121-29.

77. Thierry B, Steru L, Chermat R, et al. Searching-waiting strategy: A candidate for an evolutionary model of depression? Behav Neural Biol. 1984;41(2):180-189.

78. Bradwejn J, Zhou Y, Koszycki D, et al. A double-blind, placebocontrolled study on the effects of Gotu Kola (Centella asiatica) on acoustic startle response in healthy subjects. J Clin Psychopharmacol. 2000;20(6):680-684.

79. Hölzl J, Godau P. Receptor bindings studies with Valeriana officinalis on the benzodiazepine receptor. Planta Med. 1989;55(7):642.

80. Sharma A, Cardoso-Taketa A, García G, et al. A systematic updated review of scientifically tested selected plants used for anxiety disorders. Bot Targets Ther. 2012;2:21-39.

81. Girdhar S, Wanjari MM, Prajapati SK, et al. Evaluation of anticompulsive effect of methanolic extract of Benincasa hispida Cogn. fruit in mice. Acta Pol Pharm. 2010;67(4):417-421.

82. Prajapati RP, Kalaria MV, Karkare VP, et al. Effect of methanolic extract of Lagenaria siceraria (Molina) Standley fruits on marble-burying behavior in mice: Implications for obsessive-compulsive disorder. Pharmacognosy Res. 2011;3(1):62-66.

83. Lee MK, Kim SR, Sung SH, et al. Asiatic acid derivatives protect cultured cortical neurons from glutamate-induced excitotoxicity. Res Commun Mol Pathol Pharmacol. 2000;108(1-2):75-86.

84. Mook-Jung I, Shin JE, Yun SH, et al. Protective effects of asiaticoside derivatives against beta-amyloid neurotoxicity. $J$ Neurosci Res. 1999;58(3):417-425. 
85. Ramaswamy AS, Periyasamy SM, Basu N. Pharmacological studies on Centella asaitica Linn. (Brahma manduki)(no Umbelliferae). J Res Indian Med. 1970;4:160-175.

86. Michael S Ritsner. Handbook of Schizophrenia Spectrum Disorders. Vol III. Springer; 2011.

87. Preedy VR. Handbook of Cannabis and Related Pathologies: Biology, Pharmacology, Diagnosis, and Treatment. USA: Academic Press; 2016. $1170 \mathrm{p}$.

88. Spencer JPE. The impact of flavonoids on memory: physiological and molecular considerations. Chem Soc Rev. 2009;38(4):1152-1161.

89. Brouillet E, Beal MF. NMDA antagonists partially protect against MPTP induced neurotoxicity in mice. Neuroreport. 1993;4(4):387-390.

90. Katiyar C, Gupta A, Kanjilal S, et al. Drug discovery from plant sources: An integrated approach. Ayu. 2012;33(1):10-19.

91. Parveen A, Parveen B, Parveen R, et al. Challenges and guidelines for clinical trial of herbal drugs. J Pharm Bioallied Sci. 2015;7(4):329-333.
92. WHO-Operational Guidance: Information needed to support clinical trials of herbal products. Geneva: World Health Organization; 2005.

93. Agrawal A, Dubey ML, Dubey GP. Effects of "Mentat" on memory and anxiety scores of normal subjects in three age groups. Pharmacopsychoecologia. 1990;3:43-45.

94. Dash SK. Ginkgo Biloba in Alzheimer's Disease. Austin J Clin Neurol. 2015;2(3):1028.

95. Jahromy MH, Khakpour S, Khorgami Z. The Antidepressant-Like Effects of Punica granatum (Pomegranate) Extract in Mice. Chin Med. 2014;5(1):1-6.

96. Leite JR, Seabra M de L, Maluf E, et al. Pharmacology of lemongrass (Cymbopogon citratus Stapf). III. Assessment of eventual toxic, hypnotic and anxiolytic effects on humans. J Ethnopharmacol. 1986;17(1):75-83.

97. Zhu W, Ma S, Qu R, et al. Antidepressant Effect of Baicalin Extracted from the Root of Scutellaria baicalensis in Mice and Rats. Pharm Biol. 2006;44(7):503-510 